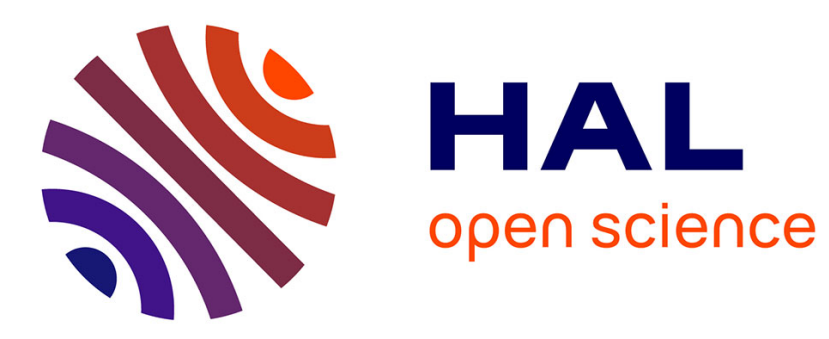

\title{
Nutrient load modelling during floods in intermittent rivers: An operational approach
}

Yin Chu, Christian Salles, Flavie Cernesson, Jean Louis Perrin, Marie-George

Tournoud

\section{- To cite this version:}

Yin Chu, Christian Salles, Flavie Cernesson, Jean Louis Perrin, Marie-George Tournoud. Nutrient load modelling during floods in intermittent rivers: An operational approach. Environmental Modelling and Software, 2008, 23 (6), pp.768 - 781. 10.1016/j.envsoft.2007.09.008 . hal-01517787

\section{HAL Id: hal-01517787 \\ https://hal.science/hal-01517787}

Submitted on 19 Nov 2019

HAL is a multi-disciplinary open access archive for the deposit and dissemination of scientific research documents, whether they are published or not. The documents may come from teaching and research institutions in France or abroad, or from public or private research centers.
L'archive ouverte pluridisciplinaire HAL, est destinée au dépôt et à la diffusion de documents scientifiques de niveau recherche, publiés ou non, émanant des établissements d'enseignement et de recherche français ou étrangers, des laboratoires publics ou privés. 


\title{
Nutrient load modelling during floods in intermittent rivers: An operational approach
}

\author{
Y. Chu ${ }^{\text {a }}$, C. Salles ${ }^{\text {a }}$, F. Cernesson ${ }^{\text {b }}$, J.L. Perrin ${ }^{\text {a, }}$ M.G. Tournoud ${ }^{\text {a,* }}$ \\ ${ }^{a}$ Université Montpellier II e HydroSciences Montpellier, UMR 5569 (CNRS e IRD e Université Montpellier 1 e Université Montpellier 2), \\ Maison des Sciences de l'Eau, Université Montpellier 2 , F-34095 Montpellier Cedex 5, France \\ ${ }^{\mathrm{b}}$ Territoires, Environnement, Télédétection et information spatiale, JRU CEMAGREF e CIRAD e ENGREF, Maison de la Télédétection, \\ 500 rue J.F. Breton, F-34093 Montpellier Cedex 5, France
}

\section{Introduction}

More than $40 \%$ of the Mediterranean basin corresponds to coastal river basins (Margat and Treyer, 2004). Most of the rivers are intermittent or even ephemeral. Because population densities are high in Mediterranean coastal areas, these basins concentrate dense urban areas, market gardening zones, industries and tourism. Thus, the rivers represent almost half the total water volumes and probably most of the pollutant loads that contribute to water quality problems in coastal Mediterranean waters (Najem et al., 2001).

Coastal Mediterranean rivers have hydrological regimes that are very similar to dry land rivers (Bull and Kirkby, 2002). Short rainfallerunoff events are separated by long dry periods. Little subsurface flow is available and the dry period flow is often mainly fed by effluents from Waste Water Treatment Plants (WWTP). Pollutants are transferred to the rivers by runoff during rainfall events or discharged directly 
and continuously in the river by sewage systems. Due to the long dry summer season, pollutants accumulate in the riverbed and in the catchment area during low flow periods. Intense rainstorms occurring at the beginning of autumn or during spring produce short flash flood events that remove the pollutants from the soils and the riverbed. It is widely recognised that during floods, pollutant fluxes can vary over several orders of magnitude (Eyre and Pont, 2003; Meybeck, 2005) and can represent the majority of the annual loads of suspended solids, nutrients and other pollutants (e.g. Cherifi and Loudiki, 1999). For small Mediterranean rivers, there is still a need for accurate evaluation of pollutant loads during flood events or over annual periods, through observation studies and modelling tools. Despite this need, observation campaigns are insufficient and existing water quality models do not accurately reproduce the behaviour of these temporary rivers.

An accurate model needs to be based on hypotheses that are suitable for the study site behaviour (Letcher et al., 2002). The model must be in accordance with both time and space variability of the processes (Donigian et al., 1995b; Leon et al., 2001; Merritt et al., 2003). Pollutant processes in a catchment are closely related to hydrological behaviour and to the heterogeneity of this behaviour with respect to geology, soil, land use and human activities (Jordan-Meille et al., 1998; Letcher et al., 2002; House, 2003; Bernal et al., 2005; Yuan et al., 2007; Shrestha et al., 2008). Consequently, event-based water quality models are more suitable than continuous models for small Mediterranean catchments. In addition, a spatially distributed approach is needed to take into account different sources of pollutant in a given catchment.

The accuracy of the model is also linked to its level of complexity: incorporation of detailed processes does not necessarily lead to a better model (Bobba et al., 2000; Durand et al., 2002; Merritt et al., 2003). The design and practice of water quality modelling lags behind that of hydrological modelling (Donigian et al., 1995b). Most widely used process-based water quality models are based on existing hydrological models, e.g. HSPF (Donigian et al., 1995a), ANSWERS (Beasley and Huggins, 1985), AGNPS (Young et al., 1995), SWAT (Arnold et al., 1995), CatchMODS (Newham et al., 2004). These models are coupled models. In coupled modelling, both the hydrological aspect and the water quality aspect share similar model approaches and face similar problems in terms of uncertainties (Vandenberghe et al., 2007). Krysanova et al. (1998), Croke and Jakeman (2001) and Letcher et al. (2002) concluded that under the same restrictive conditions, water quality prediction is much more uncertain than water yield. The errors that affect the outputs of the hydrological model lead to uncertain water quality results (e.g. Migliaccio et al.,

2007; Polyakov et al., 2007). Furthermore, the coupled models include two sets of parameters, increasing the complexity of the model.

Water quality models can also run pollutant load dynamics independently from flow simulations by directly considering driving forces (e.g. rainfall and/or irrigation) and related conditions. Some examples can be found in the literature (Cassell et al., 1998; Payraudeau et al., 2002). Uncoupled modelling should reduce model uncertainty and provide simple, practical tools for the accurate evaluation of pollutant loads at catchment scale.

In this study, the objective was to develop an operational modelling tool able to simulate pollutant loads during flood events in Mediterranean basins with intermittent rivers. To reduce the complexity of the model and the number of parameters, an uncoupled and conceptual approach was chosen. A semi-distributed rainfall-pollutant load model is presented here. Sensitivity analysis was used to check the performance of the model and the influence of the parameters on the model outputs. The complete empirical process developed to characterize the parameters is presented. The model study was carried out on 30 flood events in three Mediterranean intermittent rivers.

\section{Study area and available data}

\subsection{Catchment description}

Three small Mediterranean catchments located in the South of France, the Salaison, Vène and Pallas rivers (see Fig. 1) were studied. Annual average precipitation ranges from about $750 \mathrm{~mm}$ in the Salaison basin to less than $600 \mathrm{~mm}$ in the Pallas basin. Precipitation occurs as short intense storms mainly during autumn and spring.

The Salaison River flows into the Or lagoon and drains a $53-\mathrm{km}^{2}$ area, of which $45 \%$ corresponds to natural areas (garrigue, pine trees) and 30\% to agricultural land (orchards, vineyards and market gardening). Densely populated urban zones $\left(165\right.$ inhabitants $\left./ \mathrm{km}^{2}\right)$ represent $25 \%$ of the total catchment area. The short hydrographical network $(15 \mathrm{~km})$ receives the effluents of one major waste water treatment plant with a capacity of 23000 person-equivalents (p.e.).

The Vène and Pallas rivers are tributaries of the Thau lagoon. The Pallas catchment covers an area of $52 \mathrm{~km}^{2}$, of which $56 \%$ is agricultural land (vineyards, market gardening, orchards and cereals). It is a sparsely populated rural basin and has no significant industrial activity. A waste water treatment plant (2500 p.e.) is located in the upper part of the river. The Vène River drains an area of $67 \mathrm{~km}^{2}$. In terms of land use, $63 \%$ of the total area corresponds to natural karstic zones and $34 \%$ to agricultural zones, of which $21 \%$ are vineyards. Human activities are concentrated in the central area. About 9200 people live in three small villages. Three waste water treatment plants (total capacity 9800 p.e.) are located, respectively, in the upstream, middle and downstream parts of the river. Two intermittent karstic springs feed the Vène River.

\subsection{Monitoring network and protocols}

\subsubsection{Hydrological data}

The locations of the rain and stream gauging stations are shown in Fig. 1. The Salaison and Pallas rivers have stream gauges located at their outlets, while the Vène River has four stream gauges. The main characteristics of the catchments controlled by the stream gauges are presented in Table 1. For each stream gauge, rain data from the nearest rain gauge were used in the model. Rainfall and flow data were measured in 5-min time steps. 

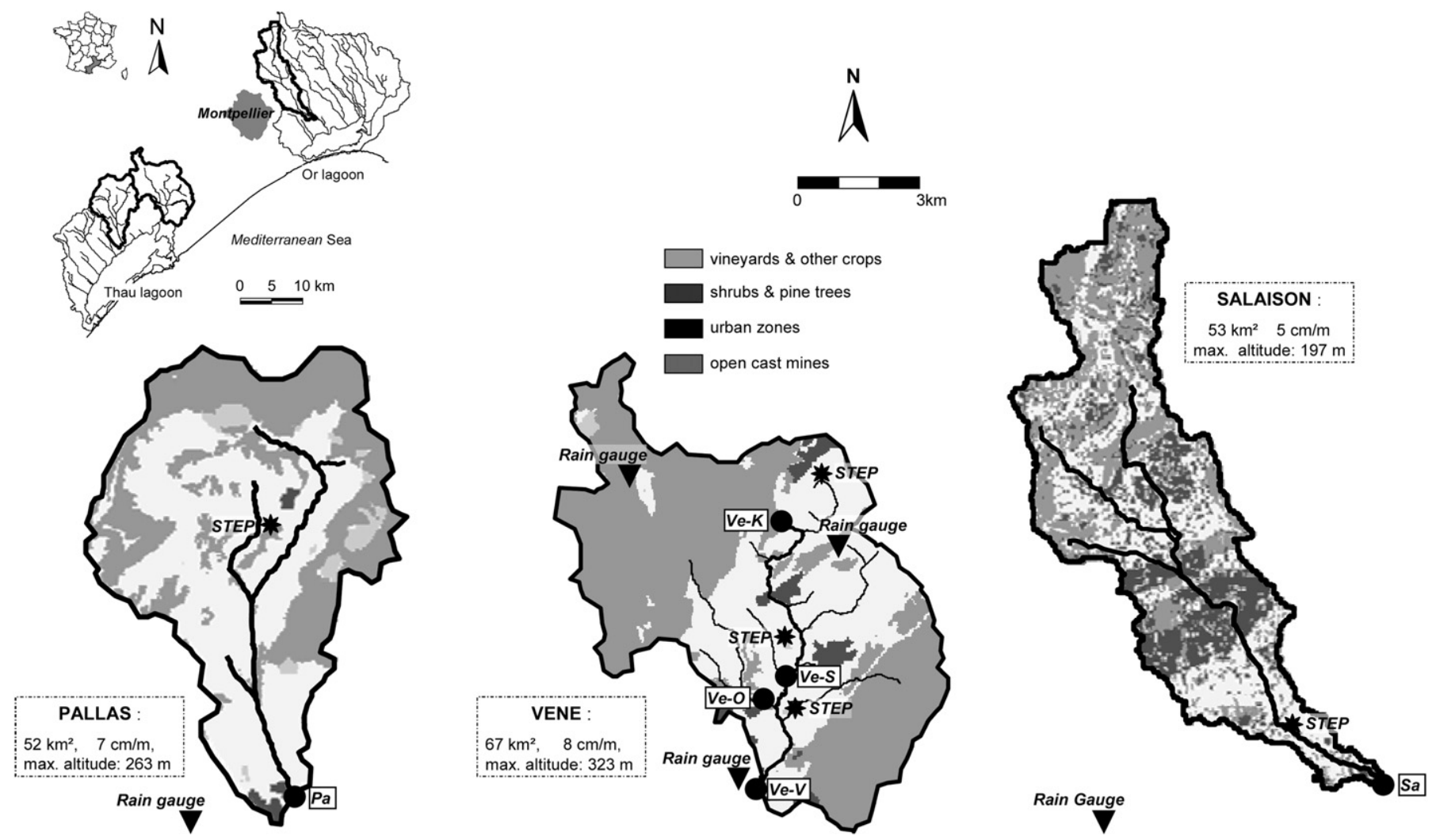

Fig. 1. The study catchments (a) overview (b) the Vène catchment (c) the Salaison catchment and (d) the Pallas catchment.

\subsubsection{Sample collection}

Automatic sampling was carried out at the stream gauges during flood events. With a few exceptions, samples were collected

at 2-h intervals during the rising flow. After the peak flow, the sampling time interval varied from $4 \mathrm{~h}$ when the flow decreased rapidly, to one day when the flood recession slowed down.

\subsubsection{Water quality characterization}

The water samples were analyzed for different forms of nitrogen and phosphorus: Dissolved Inorganic Nitrogen (DIN) concentrations are represented by nitrate, nitrite and ammonium; Dissolved Phosphorus (DP) is soluble reactive phosphorus.

\subsection{Flood events}

Thirty flood events were the subject of the study. The following descriptors were used to characterize: (i) rainfall events: total amount $\mathrm{H}(\mathrm{mm})$, duration of the rainfall event $\mathrm{Dp}(\mathrm{h})$, mean intensity of the event $\operatorname{Im}(\mathrm{mm} / \mathrm{h})$ and peak intensity in $5 \mathrm{~min} \operatorname{Ip}(\mathrm{mm} / \mathrm{h})$; (ii) antecedent hydrological conditions: base flow $\mathrm{Qb}\left(\mathrm{m}^{3} / \mathrm{s}\right)$, total rainfall amount over the last 30 days $\mathrm{H}-30(\mathrm{~mm})$, and over the last 60 days H-60 (mm); (iii) the flood: peak flow $\mathrm{Qp}\left(\mathrm{m}^{3} / \mathrm{s}\right)$, flood duration $\mathrm{Dc}(\mathrm{h})$, flood volume $\mathrm{V}\left(10^{3} \mathrm{~m}^{3}\right)$. Pollutographs of instant pollutant loads are characterised by total pollutant loads during the flood event, peak load, peak time and skewness.

Instant pollutant loads were calculated by multiplying the concentration of a given sample by the related 5-min flow data. Calculation of total load was based on 5-min flow data, using the following formula:

$\operatorname{Total}_{\operatorname{Load}{ }^{1 / 4}}^{\mathbf{X}} \underset{\mathrm{i}^{1 / 41}}{\mathrm{q} \mathrm{C}_{\mathrm{i}} \mathrm{int}} \mathrm{Dt}$

with $\mathrm{q}_{\mathrm{i}}$, instant flow of the ith time interval; $\mathrm{C}_{\mathrm{int}}$, linear interpolated value between the two nearest observed concentrations; and Dt, the time interval $(5 \mathrm{~min})$. Salles et al. (in press) demonstrated that this method for calculating total load is the least sensitive to sampling effects.

The number of samples varied from event to event. For some events very few samples were available. Sometimes there was no sample during the rising flow period. As shown by Salles et al. (in press) lack of data affects the accuracy of the estimation of total load and increases the equifinality issue during the calibration process. For that reason, in the following, observed total flood load is considered with a given uncertainty related to average frequency of sampling (i.e. the number of samples divided by the flood duration).

The characteristics of the 30 flood events are listed in Table 2. The data set was split into two parts: one for calibration purposes and the other one for validation. Event rainfall depth extended over a wide range (from 7 to $170 \mathrm{~mm}$ ) but for different durations of rainfall events. Consequently, the mean rain intensity varied less, i.e. from approximately 1 to $7 \mathrm{~mm} / \mathrm{h}$. The main difference between rain events was peak rain intensity which started at $1 \mathrm{~mm} / \mathrm{h}$ and where the high end equalled $47 \mathrm{~mm} / \mathrm{h}$. The rainfall 
Table 1

Descriptors of catchment characteristics

\begin{tabular}{|c|c|c|c|c|c|c|}
\hline \multirow[t]{2}{*}{ Study sites } & \multirow{2}{*}{$\begin{array}{l}\text { Catchment area } \\
\left(\mathrm{km}^{<}\right)\end{array}$} & \multicolumn{2}{|c|}{ Land use $(\%)$} & \multirow[b]{2}{*}{ Nature } & \multirow{2}{*}{$\begin{array}{l}\text { Population } \\
\text { inhab. }\end{array}$} & \multirow[t]{2}{*}{ WWTP p.e. } \\
\hline & & Agriculture & Urban & & & \\
\hline Salaison at the outlet (Sa station) & 53.0 & 30.0 & 25.1 & 45.1 & 15,300 & 23,000 \\
\hline Pallas at the outlet (Pa station) & 52.0 & 56.0 & 1.0 & 38.1 & 1974 & 2500 \\
\hline Vene at the outlet (Ve-V station) & 67.0 & 39.3 & 4.2 & 56.6 & 11,400 & 9800 \\
\hline Vene at $\mathrm{K}$ station (Ve-K station) & 1.6 & 18.8 & 0.0 & 81.3 & 0 & 0 \\
\hline Vene at $\mathrm{S}$ station (Ve-S station) & 35.0 & 48.9 & 5.7 & 45.4 & 7730 & 3800 \\
\hline Vene at Oulettes station (Ve-O station) & 17.6 & 24.4 & 1.7 & 73.9 & 1370 & 0 \\
\hline
\end{tabular}

events were quite contrasted in terms of antecedent hydrological conditions. The major difference was due to the first flood event occurring after the long dry summer period (e.g. the September 2003 event measured at the $\mathrm{S}$ station in the Vène catchment). The flood events lasted from a few hours (e.g. 3.4 h for the September 2004 event at the K station in the Vène) to many days (e.g. the November 1999 event at the V station in the Vène catch- ment). Peak discharge ranged from 1 to $20 \mathrm{~m}^{3} / \mathrm{s}$. Consequently DIN loads and DP loads differed between events, from less than $1 \mathrm{~kg}$ to more than $300 \mathrm{~kg}$ for DP and to more than $5000 \mathrm{~kg}$ for DIN.

\section{Model description and sensitivity analysis}

\subsection{The D-PoL model}

The D-PoL model presented here is based on the PoL model (Payraudeau et al., 2002). The PoL model (Pollutant Loads) is an uncoupled water quality model specifically developed for Mediterranean intermittent rivers. Here we describe how the model was adapted for use with dissolved elements.

\subsubsection{Space delineation}

The D-PoL model is based on a semi-distributed approach to enable the spatial variability of human activities to be taken into account. DEM data, land use, agricultural practices, point sources of pollutants (such as the location of sewage treatment plants) are required. Pollutant point sources are defined as direct inputs in the river. The river network is divided into river reaches according to the location of point source, main tributaries and drainage areas. The catchment is delineated into hydrological units with comparable drainage area (Rodriguez-Iturbe and Gupta, 1983) by topography. For each unit (sub-catchment or river reach), geomorphologic characteristics (area, slope, length) and land use characteristics are processed (Payraudeau et al., 2001).

\subsubsection{Model structure}

Two processes are considered in the model: (i) the production of dissolved pollutant loads by the hydrological units during the rainfall event; and (ii) the routing of these loads along the river reach. Two hypotheses are assumed: (i) rainfall drives pollutant mobilisation in sub-catchment areas; and (ii) pollutant loads are conservative along the river reaches during the event. Fig. 2 summarises the conceptualisation of the model.
The production process in a given sub-catchment is represented by a simple linear reservoir (Fig. 2a). At the beginning of the rainfall event, each reservoir is initialized with an initial stock of pollutants that is a linear function of the agricultural area of the catchment. The coefficient of the linear function is St, the elementary initial stock of pollutant, expressed in mass per agricultural surface unit. St is set by calibration.

All the production reservoirs have the same lag time which is time-dependent and related to the cumulative rainfall amount through a linear filter function. The slope of the filter function depends on the mean annual rainfall of the study site. The cumulative rainfall amount is equal to the level of rainfall accumulated in a reservoir. The linear output of the reservoir is controlled by a lag time coefficient a; F $1 / 41 / a$ is the second parameter of the model that is set by calibration (Fig. 2b).

The routing process along a river reach is represented by a series of linear reservoirs. At the beginning of the rainfall event, the routing reservoirs are all empty. The lag time $\mathbf{t}$ of the river reservoirs is assumed to be uniform over the whole river network. $\mathrm{T} 1 / 41 / \mathrm{t}$ is the third parameter set by calibration of the model (Fig. 2c). The number of reservoirs for a given reach is the ratio of the reach length to the minimum reach length of the study site.

\subsubsection{Model specifications}

The model is run during rainfall events. The input data are hourly rainfall data and average hourly effluent loads from direct inputs. The model outputs are hourly pollutant loads at the catchment outlet. The simulation is stopped when the load at the outlet is less than $110 \%$ of direct pollutant inputs. The model equations are solved at a time step consistent with the stability and the convergence of the numerical equations.

The D-PoL model has: (i) two functions that depend on the characteristics of the study site and involve the mean annual rainfall amount as well as the minimum reach length; and (ii) three parameters to be decided by calibration: the elementary initial stock of pollutants $(\mathrm{St})$, the production parameter $(\mathrm{F})$ and the routing parameter $(\mathrm{T})$. In our case studies, the mean annual rainfall amount was set to $800 \mathrm{~mm}$ and the minimum reach length to $850 \mathrm{~m}$. The elementary initial stock of pollutants St ranged from 0 to $10 \mathrm{~kg} / \mathrm{ha}$. According to the agricultural practices in these basins, using St values higher than $10 \mathrm{~kg} / \mathrm{ha}$ would be unrealistic (Payraudeau et al., 2001). The production parameter $\mathrm{F}$ varied from 0.1 to $1 \mathrm{~h}^{1}$; this range of values fits with the hydrological behaviour of small 
Table 2

Descriptions of event characteristics

\begin{tabular}{|c|c|c|c|c|c|c|c|c|c|c|c|c|c|c|}
\hline Basin & & Event \# & Event date & $\mathrm{H}(\mathrm{mm})$ & $\operatorname{Im}(\mathrm{mm} / \mathrm{h})$ & $\mathrm{Ip}(\mathrm{mm} / \mathrm{h})$ & $\mathrm{H}-30(\mathrm{~mm})$ & $\mathrm{H}-60(\mathrm{~mm})$ & $\mathrm{Qb}\left(\mathrm{m}^{3} / \mathrm{s}\right)$ & $\mathrm{Qp}\left(\mathrm{m}^{3} / \mathrm{s}\right)$ & $\mathrm{D}(\mathrm{h})$ & $\mathrm{V}\left(10^{3} \mathrm{~m}^{3}\right)$ & DIN load (kg-N) & DP load (kg-P) \\
\hline \multirow{20}{*}{$\begin{array}{l}\text { Data set for parameter } \\
\text { adjustment }\end{array}$} & \multirow[t]{2}{*}{ Pallas } & 1 & Oct 94 & 118.8 & 4.1 & 15 & 116 & 181.8 & 0.01 & 8.1 & 131.6 & 1500 & 2702.4 & 107.4 \\
\hline & & 2 & Apr 96 & 6.8 & 1.7 & 4.6 & 14.6 & 154.4 & 0.13 & 0.9 & 16.1 & 24 & 48.4 & 2.4 \\
\hline & \multirow[t]{7}{*}{ Salaison } & 3 & Mar 99 & 16.6 & 1.7 & 5.6 & 6.6 & 8.8 & 0.17 & 1.1 & 18.8 & 27 & 200.9 & 27.2 \\
\hline & & 4 & Apr 99 & 39.2 & 3 & 18 & 19 & 52.6 & 0.06 & 1.8 & 19.3 & 38 & 156.4 & 25.8 \\
\hline & & 5 & May 99 & 55.2 & 3.2 & 7.9 & 86.8 & 120.4 & 0.43 & 4.2 & 27.5 & 190 & 312.9 & 27.2 \\
\hline & & 6 & Sept 99 & 44.2 & 7.4 & 30.8 & 45.4 & 86.2 & 0.05 & 5.8 & 29.6 & 55 & 302.7 & 84.4 \\
\hline & & 7 & Oct 99 & 24.6 & 1.5 & 7.5 & 64 & 172.8 & 0.34 & 4.3 & 33.5 & 230 & 450.1 & 47.7 \\
\hline & & 8 & Nov 99 & 84.8 & 2.9 & 10 & 107.8 & 175.4 & 0.57 & 8.4 & 66.3 & 830 & 1895.7 & 78.8 \\
\hline & & 9 & Apr 00 & 34.4 & 4.3 & 15.2 & 32.2 & 33. & 0.1 & 1.9 & 14.1 & 40 & 223 & 23.6 \\
\hline & Vene_K & 10 & Sept 04 & 50.6 & 4.2 & 38.4 & 47.4 & 69.4 & 0 & 1.6 & 3.2 & 3.4 & 1.3 & 0.1 \\
\hline & \multirow[t]{2}{*}{ Vene_O } & 11 & Nov 03 & 41.7 & 3 & 12.3 & 30.5 & 108.5 & 0.015 & 1.2 & 16.2 & 20 & 35.2 & 0.8 \\
\hline & & 12 & Sept 04 & 113.7 & 4.4 & 52.7 & 37.2 & 55 & 0 & 2.8 & 30.1 & 28 & 33.7 & 2.7 \\
\hline & \multirow[t]{3}{*}{ Vene_S } & 13 & Sept 03 & 87 & 7.3 & 31.5 & 3.5 & 38.6 & 0.002 & 8.3 & 8.5 & 150 & 271.7 & 29.6 \\
\hline & & 14 & Sept 04 & 28 & 2.5 & 20.6 & 25.5 & 25.6 & 0.003 & 1.7 & 6.9 & 9.2 & 16.4 & 5.6 \\
\hline & & 15 & Sept 04 & 65.4 & 1.9 & 38.6 & 32.3 & 54.3 & 0.002 & 10.7 & 83.7 & 180 & 242.7 & 31.6 \\
\hline & \multirow[t]{5}{*}{ Vene_V } & 16 & Oct 94 & 160.2 & 3.9 & 32 & 165 & 240.4 & 0.38 & 18.1 & 67.8 & 3600 & 3474.8 & 246.3 \\
\hline & & 17 & Sept 99 & 70.6 & 7.1 & 36.2 & 46.6 & 71.4 & 0 & 19.6 & 13 & 420 & 309.2 & 92.1 \\
\hline & & 18 & Oct 99 & 66.2 & 3.9 & 17.4 & 32.2 & 147.6 & 0.06 & 5.7 & 13.2 & 210 & 192 & 16.1 \\
\hline & & 19 & Sept 03 & 49.4 & 8.2 & 24.8 & 39.6 & 42.9 & 0.02 & 11.8 & 8.7 & 170 & 289.2 & 26.1 \\
\hline & & 20 & Sept 04 & 104.3 & 3 & 47.3 & 25.6 & 44.9 & 0.001 & 20.5 & 85.4 & 490 & 619.4 & 90.1 \\
\hline \multirow[t]{10}{*}{ Data set for validation } & \multirow[t]{2}{*}{ Pallas } & 21 & Sept 94 & 30.6 & 2.8 & 12.6 & 93.6 & 106 & 0.02 & 1.2 & 9.8 & 18 & 32.9 & 5.9 \\
\hline & & 22 & Mar 96 & 67.2 & 1.5 & 3.4 & 72.6 & 185.2 & 0.33 & 6.8 & 121.6 & 1300 & 2298.9 & 60.2 \\
\hline & Vene_K & 23 & Sept 03 & 62.3 & 6.2 & 22.5 & 2.4 & 36.7 & 0 & 1 & 4.9 & 3.8 & 4.2 & 0.5 \\
\hline & \multirow[t]{3}{*}{ Vene_O } & 24 & Sept 03 & 28.8 & 1.3 & 7.9 & 4.8 & 41.2 & 0 & 6.1 & 68 & 270 & 329.4 & 7 \\
\hline & & 25 & Sept 04 & 16.6 & 1.5 & 12.4 & 21.9 & 22.9 & 0 & 0.1 & 3.5 & 0.36 & 0.6 & 0.03 \\
\hline & & 26 & Feb 05 & 47.3 & 1.4 & 4.9 & 3.9 & 35.8 & 0.013 & 0.2 & 19.7 & 2.5 & 10.8 & 0.3 \\
\hline & \multirow[t]{4}{*}{ Vene_V } & 27 & Sept 94 & 15 & 1.4 & 5.2 & 132.9 & 81.2 & 0.08 & 1.4 & 40.3 & 130 & 126 & 19.9 \\
\hline & & 28 & Mar 96 & 55.6 & 0.4 & 1.1 & 21.4 & 48.2 & 2.54 & 16 & 413 & 7300 & 5395.1 & 303 \\
\hline & & 29 & May 99 & 76.8 & 3.2 & 7.6 & 84.2 & 102.2 & 0.05 & 8.7 & 46.3 & 770 & 931 & 66.1 \\
\hline & & 30 & Nov 99 & 167.2 & 2.5 & 10.7 & 130 & 180.2 & 0.24 & 21.1 & 223.1 & 7000 & 4706 & 344.1 \\
\hline
\end{tabular}


Model scheme and parameter description

(a) Pollutant production on a sub-catchment

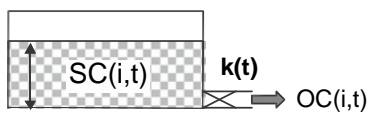

St: initial stock of per hectare of agriculture landuse $(\mathrm{kg} / \mathrm{ha})$ $=$ to be fitted by calibration

\section{(b) Rainfall trigger}

Rain(t)

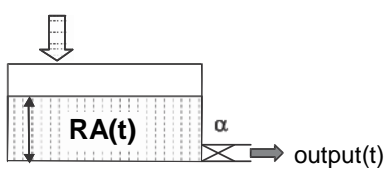

$\boldsymbol{R}_{\text {max }}$ : maximum rainfall accumulation (= mean annual rainfall: $800 \mathrm{~mm}$ )

$\boldsymbol{F}$ : production parameter $(\mathrm{h}-1)=$ to be fitted by calibration
Equations

(1) $\frac{d S C(i, t)}{d t}=-O C(i, t)$

(2) $\mathrm{OC}(\mathrm{i}, \mathrm{t})=\mathrm{k}(\mathrm{t}) \times \mathrm{SC}(\mathrm{i}, \mathrm{t})$

(3) $\mathrm{SC}(\mathrm{i}, 0)=\mathbf{S t} \times \mathrm{Sa}(\mathrm{i})$

$\mathrm{SC}(\mathrm{i}, \mathrm{t})$ : pollutant stock in the $\mathrm{i}^{\text {th }}$ sub-catchment $(\mathrm{kg})$ $\mathrm{OC}(\mathrm{i}, \mathrm{t})$ : pollutant output from the $\mathrm{i}^{\text {th }}$ sub-catchment $(\mathrm{kg} / \mathrm{h})$ $k(t)$ : production coefficient $\left(h^{-1}\right)$

$\mathrm{Sa}(\mathrm{i})$ : agriculture area of the $\mathrm{i}^{\text {th }}$ sub-catchment (ha)

$$
\text { (4) } \frac{\mathrm{dRA}(\mathrm{t})}{\mathrm{dt}}=\operatorname{Rain}(\mathrm{t})-\operatorname{output}(\mathrm{t})
$$

(5) output(t) $=(1 / \alpha)^{\star} \mathrm{RA}(\mathrm{t})$

(6) $\boldsymbol{F}=1 / \alpha$

(7) $\mathrm{k}(\mathrm{t})=\mathrm{RA}(\mathrm{t}) / \mathrm{RA} \mathrm{A}_{\max }$, if $\mathrm{RA}(\mathrm{t})<\mathrm{RA} \mathrm{A}_{\max }$ $k=1$, if $R A(t)>=R A_{\text {max }}$

Rain(t): rainfall $(\mathrm{mm} / \mathrm{h})$

$\mathrm{RA}(\mathrm{t})$ : rainfall accumulation $(\mathrm{mm})$

output(t): output from the trigger reservoir $(\mathrm{mm} / \mathrm{h})$ $\alpha$ : lag-time of the trigger reservoir (h)

\section{(c) Routing along a river reach}

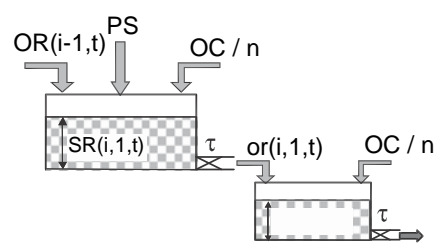

$\mathrm{SR}(\mathrm{i}, 2, \mathrm{t})$

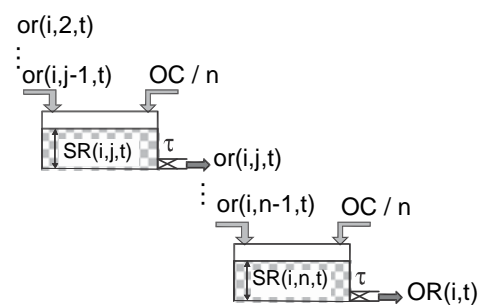

Lb: basic reach length $(=850 \mathrm{~m})$

$\mathbf{T}$ : transport parameter $\left(\mathrm{h}^{-1}\right)=$ to be fitted by calibration.

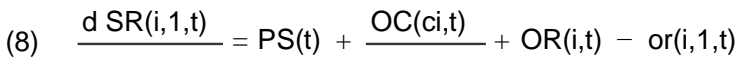

$\mathrm{dt} \quad \mathrm{n}(\mathrm{i})$

(9)

$\frac{d S R(i, j, t)}{d t}=\frac{O C(c i, t)}{n(i)}+\operatorname{or}(i, j-1, t)-\operatorname{or}(i, j, t), 1<j<n(i)$

(10)

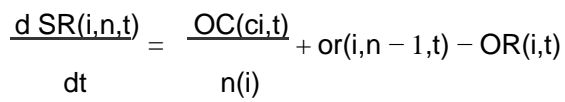

(11) $\operatorname{or}(\mathrm{i}, \mathrm{j}, \mathrm{t})=(1 / \tau)^{\star} \mathrm{SR}(\mathrm{i}, \mathrm{j}, \mathrm{t}), 1 \leq \mathrm{j} \leq \mathrm{n}(\mathrm{i})$

(10) $\boldsymbol{T}=1 / \tau$

(11) $n(i)=L(i) / L b$

$\mathrm{SR}(\mathrm{i}, \mathrm{j}, \mathrm{t})$ : stock in the $\mathrm{j}^{\text {th }}$ reservoir of the $\mathrm{i}^{\text {th }}$ river reach $(\mathrm{kg})$ $n(i)$ : total number of reservoirs of the $i^{\text {th }}$ reach

$\mathrm{L}(\mathrm{i})$ : length of the $\mathrm{i}^{\text {th }}$ reach

PS(t): point source input $(\mathrm{kg} / \mathrm{h})$

$\mathrm{OC}(\mathrm{ci}, \mathrm{t})$ : pollutant input from the related ci subcatchment $(\mathrm{kg} / \mathrm{h})$

OR(i,t): pollutant output from the $\mathrm{i}^{\text {th }}$ reach $(\mathrm{kg} / \mathrm{h})$

$\mathrm{T}$ : the lag-time of the river reservoirs $(\mathrm{h})$

Fig. 2. Description of the structure and equations of the D-PoL model.

Mediterranean catchments that show lag times of a few hours (Camarasa and Segura, 2001). The routing parameter T ranged from 0.5 to $6 \mathrm{~h}^{1}$, these values match a mean routing velocity of about $1 \mathrm{~m} / \mathrm{s}$.
Saltelli (2000) stated that sensitivity analysis is a prerequisite for model building. The main purpose of sensitivity analysis is to understand the general behaviour of a model in order

\subsection{Sensitivity analysis}


to evaluate its confidence (Chapra, 1997), but it could also be useful to interpret results during the calibration phase (Kleijnen, 2005).

The sensitivity of the model outputs to the different parameters had already been evaluated in terms of total load or event duration (Payraudeau et al., 2002). For more accuracy, other descriptors of the pollutograph dynamics were added in this study: peak load, peak time and skewness. A free univariate screening analysis (Campolongo et al., 2000; McIntyre et al., 2005) was performed that consisted in evaluating the 
impact of changing the values of factors, one by one, in turn. This sampling technique is very simple and low in computational cost. Three series of tests were conducted, one for each parameter. The sensitivity analysis was performed on a virtual catchment that is a schematic representation of the Salaison basin (Fig. 3). The pollutant event was driven by a short and intense rain event: $30 \mathrm{~mm}$ of rainfall in $1 \mathrm{~h}$.

The first test was carried out on the initial stock of pollutants, St, with different couples of values for the production and routing parameters (Fig. 4a, b). The second and third tests were carried out on the production and routing parameters, with an initial stock of pollutants of $1 \mathrm{~kg} / \mathrm{ha}$ (Fig. 4cef). These tests demonstrated that: (i) whatever the value of the initial stock of pollutants, the peak time, the event duration and the skewness of the pollutograph remained unchanged; (ii) whatever the value of the production parameter, the peak time remained unchanged; (iii) whatever the value of the routing parameter, within the range $0.5 \mathrm{e} 6 \mathrm{~h}{ }^{1}$, the total load remained unchanged; (iv) the peak value and the total load varied in the same way as the initial stock; and (v) the skewness of the pollutograph was

related equally to production and routing parameters.

This sensitivity analysis demonstrated that, for a given

catchment and for given rainfall characteristics, each parameter had an important influence on one characteristic of the pollutograph:

the initial stock of pollutant, St, influenced only the amplitude of the pollutograph (peak load and total load) without influencing its dynamic;

the production parameter, $\mathrm{F}$, influenced the event duration by modifying the recessing time; and

the routing parameter, $\mathrm{T}$, controlled the rising part of the pollutograph, through the peak time.

Consequently the calibration process became simpler (Wagener et al., 2003) even if co-effects were still present: all three parameters affected peak load; total load was influenced jointly by $\mathrm{F}$ and $\mathrm{St}$, while $\mathrm{T}$ and $\mathrm{F}$ both affected skewness.

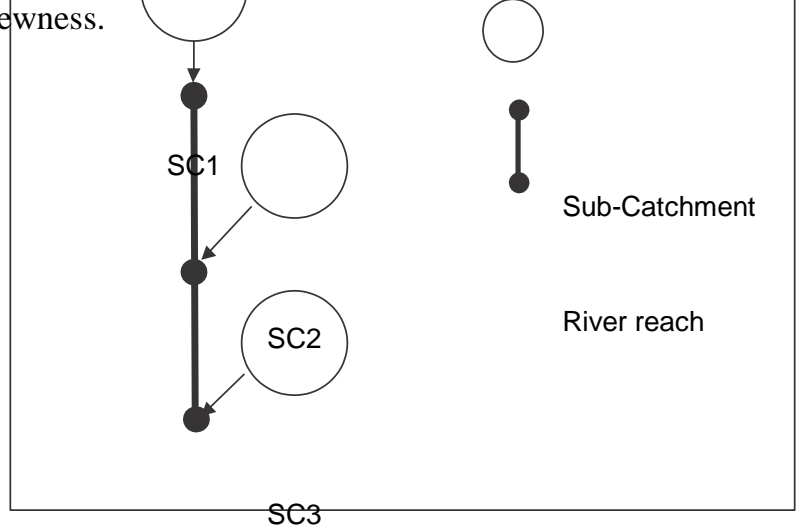

\section{Model application}

The model was applied with the following main aims: to turn the model into an operational tool and to evaluate the er- ror of the simulated total pollutant load. The set of 30 floods was divided into two sub-sets: the best sampled floods were kept in the calibration sub-sets, as Salles et al. (in press) dem- onstrated that a minimum of four samples a day are needed to obtain an accurate estimate of the total load value. The 10 other floods were put in a validation sub-set.

\subsection{Performance of the model}

Firstly, the whole parameter space was explored to check the performance of the model (Table 3). The model was run for the 14,336 nodes of the grid, for the 20 floods and for both DIN and DP. The performance of the model was evaluated for DIN and DP, by an objective function OF based on the Nash criterion (Nash and Sutcliffe, 1970):

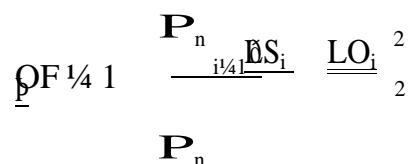

Fig. 3. The virtual catchment used for the sensitivity analysis of the D-PoL model. 


$$
{ }_{i 1 / 41} \partial \mathrm{LO}_{\mathrm{i}} \quad \mathrm{LOP}
$$

where $\mathrm{LO}_{\mathrm{i}} / \mathrm{LS}_{\mathrm{i}}$ stand for the ith observed/simulated instant pollutant (DIN or DP) load, respectively, LO is the mean of the $n$ instant load observed during the event. Model runs giving an OF greater than $70 \%$ were considered acceptable. Unacceptable runs were found for four flood events. These failures may be related to poor sampling of the flood but also to a possible karst contribution during the flood event.

The distributions of parameters giving acceptable runs are shown in box plots (Fig. 5), for DIN and DP simulations. It should be noted that the distributions of the three parameters did not depend on the catchment or on the season. The distributions of the initial stock of pollutants were quite narrow for both DIN and DP, but mean values (cross symbols plotted in Fig. 5) covered a wide range for both DIN (from 0.4 to $3 \mathrm{~kg}-\mathrm{N} / \mathrm{ha})$ and for DP $(0.02 \mathrm{e} 0.67 \mathrm{~kg}-\mathrm{P} / \mathrm{ha})$. The distributions of the routing parameters differed significantly between events. For some events, distribution was very narrow. As for the initial stock, the routing parameter showed marked variations in mean values $\left(0.4\right.$ e $5.3 \mathrm{~h}^{1}$ for DIN; $1.7 \mathrm{e} 5.8 \mathrm{~h}^{1}$ for DP). In contrast, the distributions of the production parameters were wide while the range of mean values was narrow $(0.5 \mathrm{e}$

$0.8 \mathrm{~h}^{1}$ for DIN; $0.3 \mathrm{e} 0.9 \mathrm{~h}^{1}$ for DP). It was thus possible to choose a common value of the production parameter that could provide acceptable runs for all the floods, both for DIN and for DP, as done by Payraudeau et al. (2002). Based on the average lag time of the catchments, the production parameter value was set to $0.6 \mathrm{~h}^{1}$ for the following steps.

\subsection{Characterization of the parameters}

During the second calibration step, the production parameter was fixed, and a multi-start algorithm was used to optimize the two remaining parameters (routing parameter $\mathrm{T}$ and initial stock $\mathrm{St}$ ), following the procedure proposed by Sorooshian and 
(a)

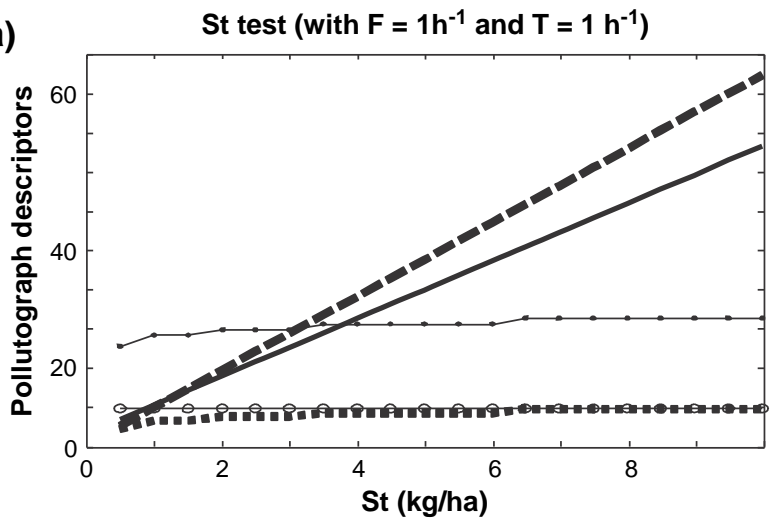

(c)

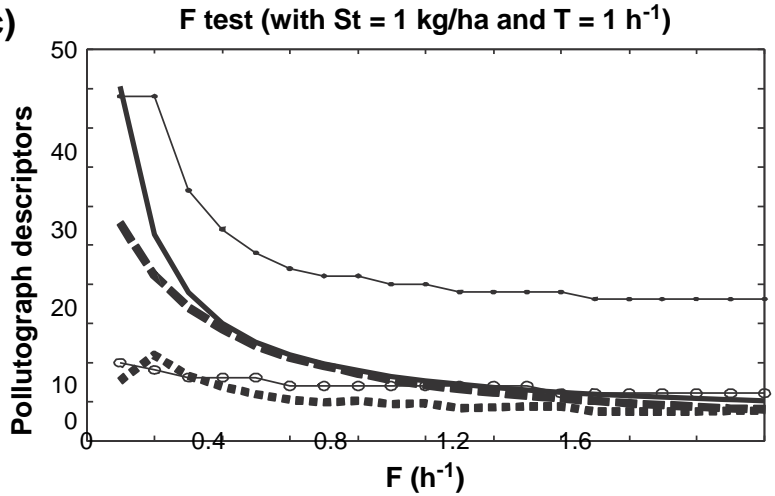

(e)

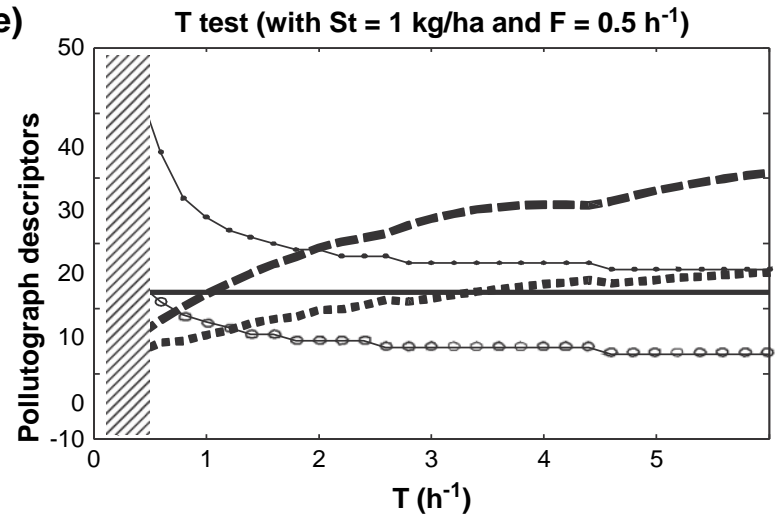

(b)

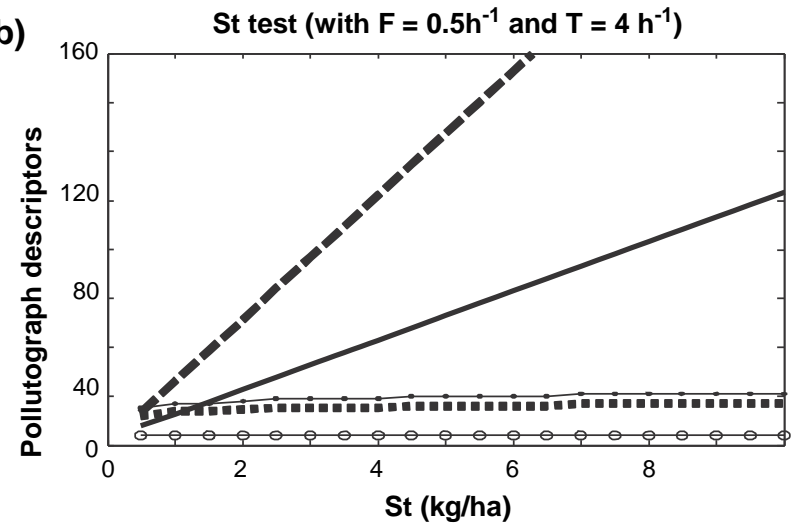

(d)

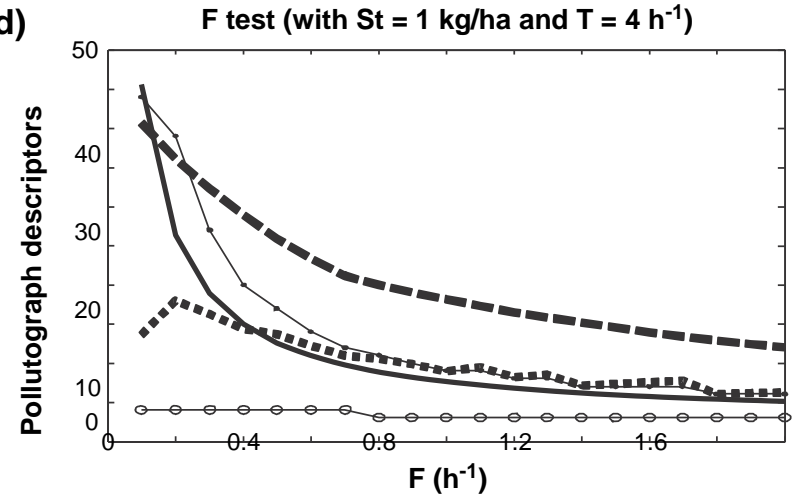

(f)

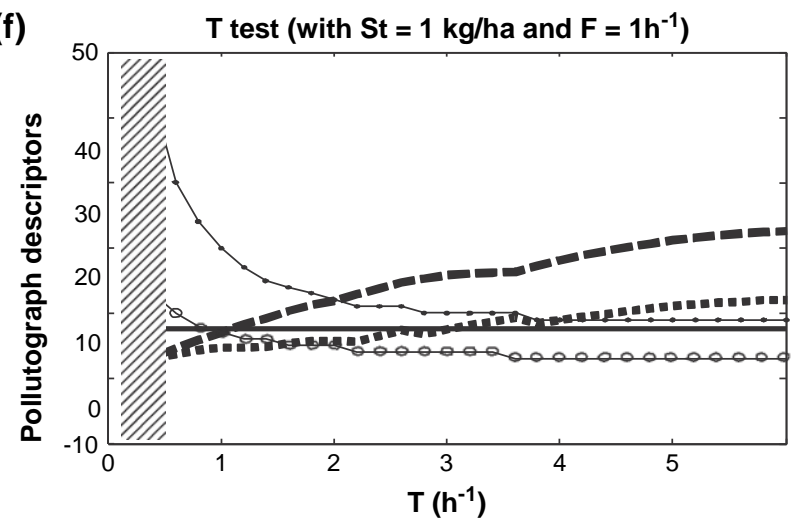

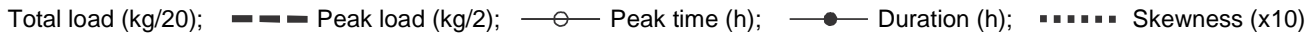

Fig. 4. Sensitivity analysis: Influence of the parameter values on the main pollutograph descriptor. Influence of the initial stock of pollutant St (a, b), the production parameter $\mathrm{F}(\mathrm{c}, \mathrm{d})$ and the routing parameter $\mathrm{T}(\mathrm{e}, \mathrm{f})$.

Gupta (1995). The (T, St) space was meshed in a 64-node regular grid. Each node was used as an initial starting set of parameters, and, for each flood, a local optimization process was run using the Fletcher and Powell (1963) method. For

Table 3

Range of parameter values for the exploration of the space parameter

\begin{tabular}{llll} 
Parameter & Units & Range & Number of step \\
\hline $\mathrm{F}$ & $\mathrm{h}^{1}$ & {$[0,1]$} & 14 \\
$\mathrm{~T}$ & $\mathrm{~h}^{1}$ & {$[0,6]$} & 32 \\
$\mathrm{St}_{\text {DIN }}$ & $\mathrm{kg}-\mathrm{Nha}{ }^{1}$ & {$[0,2]$} & 32 \\
$\mathrm{St}_{\mathrm{DP}}$ & $\mathrm{kg}-\mathrm{Pha}{ }^{1}$ & {$[0,20]$} & 32
\end{tabular}

each flood, the set of optimal parameters giving the best objective function was chosen as the set of best parameters.

For the 20 floods, both models (DIN and DP) were calibrated with $\mathrm{OF}$ greater than $50 \%$. Multiple regression analyses were run between the optimal $(\mathrm{T}, \mathrm{St})$ couples as well as the descriptors of the rain events and the catchments, using a forward stepwise method (Table 4). For both models, the descriptors of the physical characteristics of the river basins (catchment area, river length, etc.) did not appear as main explanatory factors.

For the DIN model, the routing parameter was well explained by the initial hydrological conditions (represented by the negative impact of the rainfall amount over the 60 days 
(a)
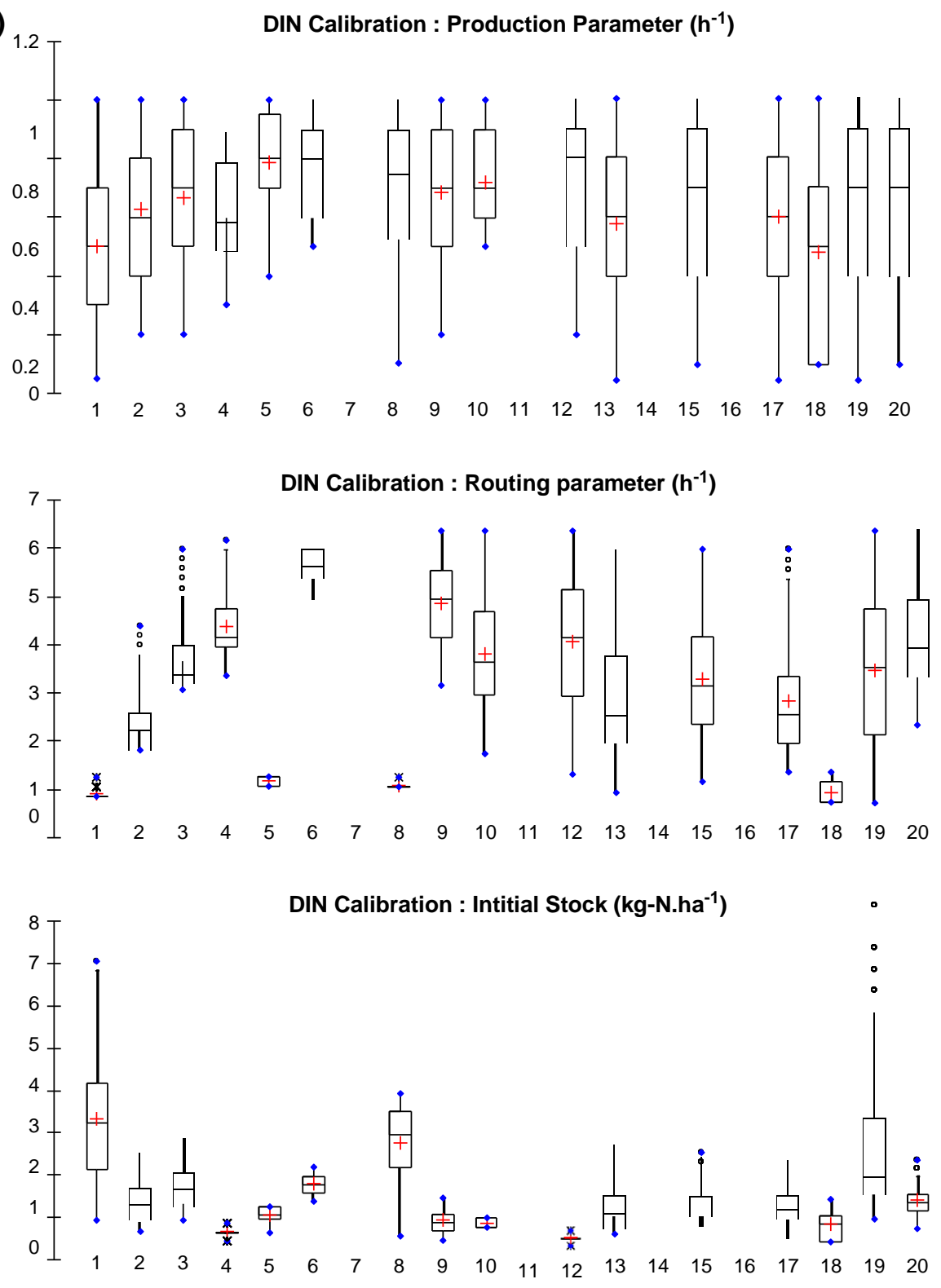

Fig. 5. Distribution of parameters giving an objective function greater than 70 for calibration of Dissolved Inorganic Nitrogen (DIN) (a) and for calibration of Dissolved phosphorus (DP) (b). The box indicates the 1st quartile, median and 3rd quartile. The mean (cross) maximum and minimum (black dot) and outlier (empty dot) are plotted for the 20 calibration events. The event number is given in Table 2.

before the flood, H-60) and the event characteristics (positive impact of the mean rainfall intensity, Im): dissolved nitrogen loads are easily transferred in the riverbed in the case of wet initial conditions and high mean flow speed. The initial DIN stock was well explained by the agricultural areas and the hydrological conditions (represented by the positive impact of H-30): dissolved nitrogen loads result from the agricultural activities and are easily leached from soils in the case of wet initial conditions.

For the DP model, the routing parameter was only explained by event characteristics (total rainfall amount $\mathrm{H}$ and peak intensity Ip): dissolved phosphorus loads are easily transferred by intense events. The initial DP stock was not well explained. The descriptors of the events and the catchments explained less than $20 \%$ of the variance of St.

\subsection{Validation with adjusted parameters}

The adjusted values of the three parameters were entered in the model specifications and the DIN and DP models were rerun for the 20 floods of the calibration sub-set. The results are shown in Fig. 6a, b. Both models gave OF greater than $50 \%$ for all the events. The dynamics of the pollutograph were well reproduced for both DIN and DP. Yet the simulated pollutographs often showed under-estimations of the DIN and DP loads at the end of the event.

Simulated total loads are plotted against observed loads in Fig. 7. The simulated total loads showed good agreement with observed loads. The distributions of the relative errors between observed and simulated total loads showed that for $75 \%$ of the floods, the model simulated the DIN and DP total loads with 
(b)
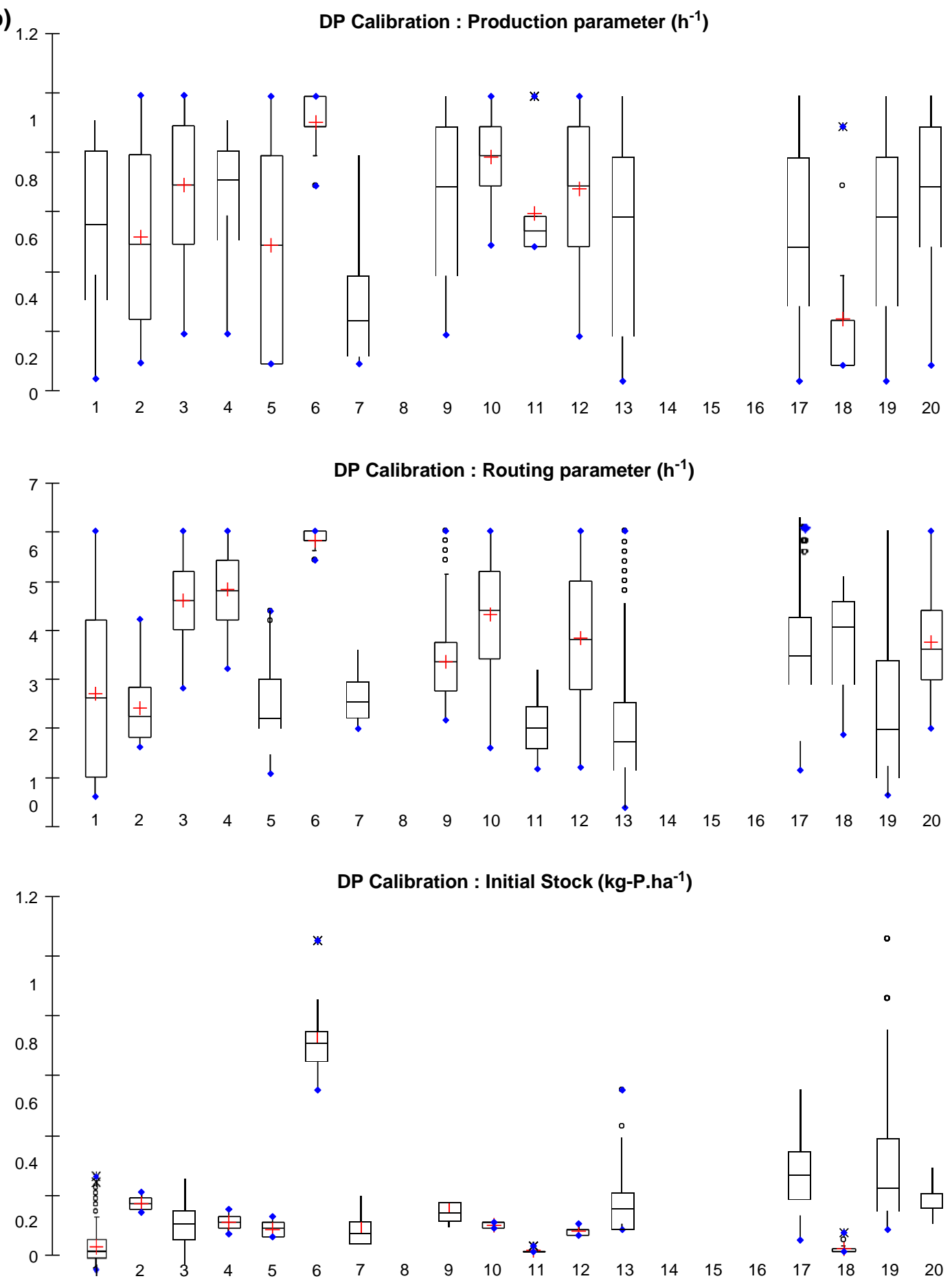

Fig. 5. (continued)

a relative error of less than $61 \%$ and $94 \%$, respectively. The highest relative error was observed for the smallest flood event: $64 \mathrm{~kg}-\mathrm{N}$ was observed while $16 \mathrm{~kg}-\mathrm{N}$ was simulated by the model. Consequently, the model error on total load was set to the third quartile of the distribution.

\subsection{Validation with the external data set}

In the final stage, the model was run for the validation of sub-set flood events. Fig. 8aec depict examples of simulated versus observed pollutographs. The simulated pollutographs follow the observed dynamic but do not compare very well with the magnitude, especially for the DIN load. Neverthe- less, the range of simulated and observed values is compara- ble. Fig. $8 \mathrm{c}, \mathrm{d}$ presents the same results in a different form. As in McIntyre et al. (2005), simulated and observed con- centrations are plotted against time. The simulated concen- tration was derived from the simulated load divided by the observed discharge at the time of sampling. These figures demonstrate that, for the validation step, the ranges of the 
Table 4

Linear regression functions relating the parameters $\mathrm{T}$ and St of DIN and DP models to explanatory variables

\begin{tabular}{llll}
\hline & Explanatory & Weights & Determination \\
\hline & variables & & coefficient $\mathrm{R}^{2}$ \\
T (DIN model) & H-60 & 0.018 & 0.61 \\
& Im & 0.15 & \\
& Constant & 3.65 & \\
T (DP model) & H & 0.05 & 0.76 \\
& Ip & 0.13 & \\
& Constant & 3.4 & \\
St (DIN model) & H-30 & 0.02 & 0.52 \\
& Agriculture & 0.04 & \\
& Constant & 0.4 & \\
St (DP model) & Im & 0.02 & 0.19 \\
& Agriculture & 0.003 & \\
& & & \\
& Constant & 0.005 & \\
& & & \\
\hline
\end{tabular}

(a)

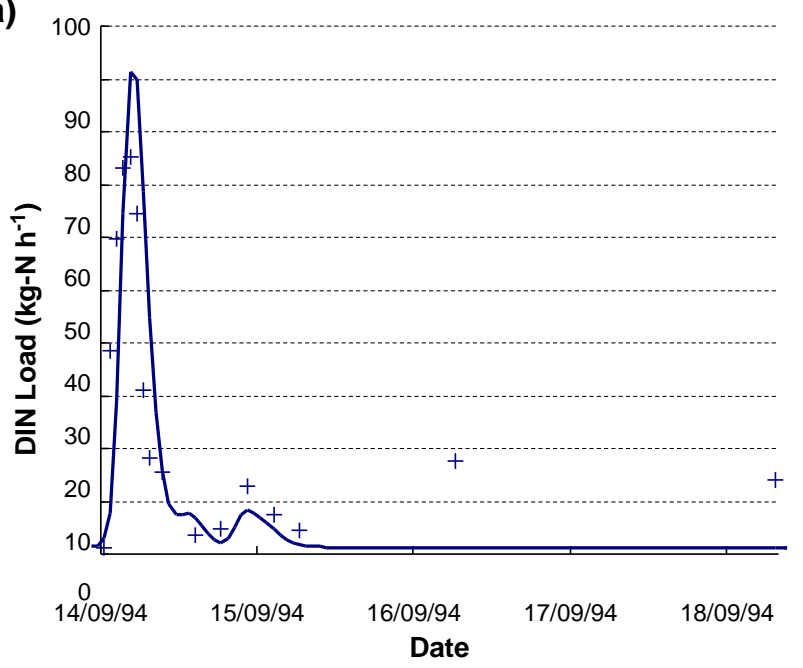

(b)

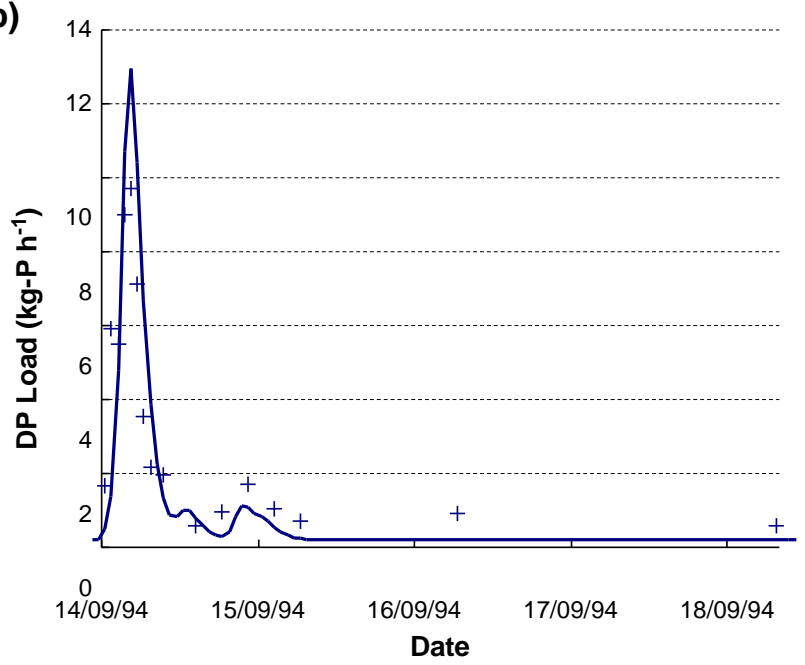

(a)

10000

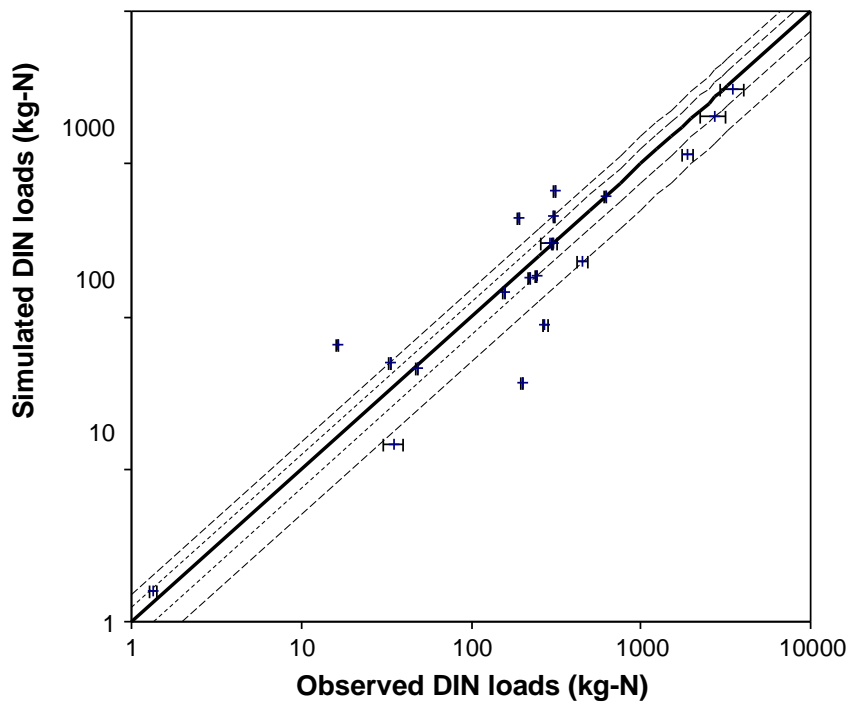

(b)

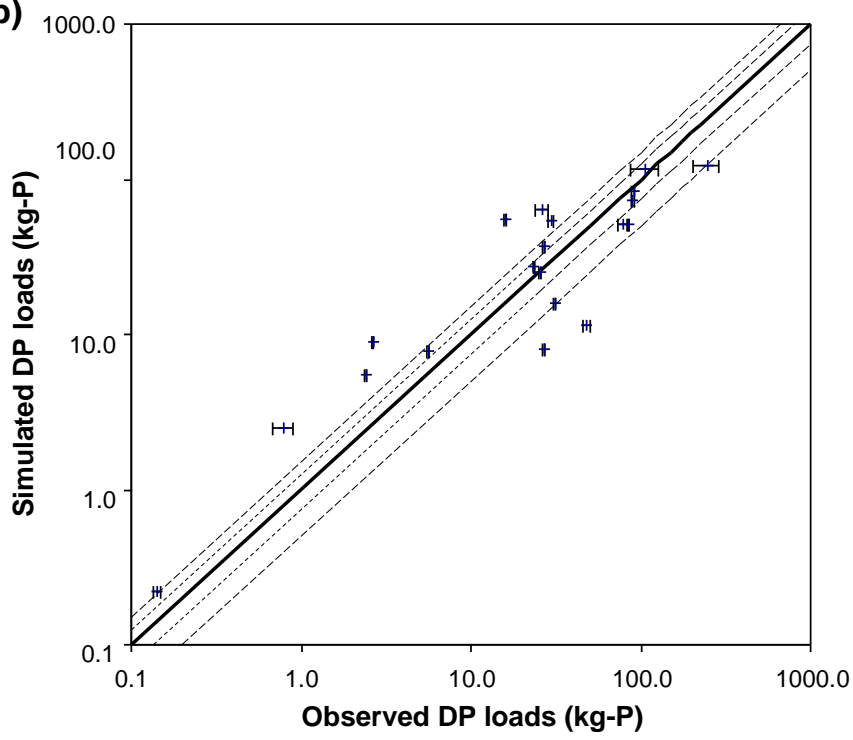

Fig. 7. Validation of adjusted parameters: Simulated pollutograph estimated using adjusted parameters versus observed loads. The thin line is the 1:1 slope, and the dashed line, long dashes and short dashes are respectively the 1.25 $(0.75)$ and $1.5(0.5)$ slopes. Uncertainties in observed values were evaluated according to the average sampling frequency (i.e. the number of samples per day used to describe the flood).

Fig. 6. Simulated pollutographs obtained using adjusted parameters for the Sept 2004 event at the V outlet of the Vène basin. (a) DIN pollutograph and (b) DP pollutograph. Measured load (crosses) and simulated load (thin line). 
simulated concentration are in accordance with the observed concentration.

Simulated total loads are plotted against observed loads in Fig. 9aeb. The error bars for simulated values correspond to the relative error of the model, as previously evaluated. For observed loads, the errors are estimated from the mean sampling frequency. Error quantification was evaluated following the results of Salles et al. (in press). Except for three flood events out of the ten used for validation, DIN loads were quite well estimated by the D-PoL model. The points on Fig. 9a are on or very close to the 1:1 slope line. The three flood events that are located far from the 1:1 slope line occurred in two different basins. The events are: (i) the September 1994 flood at the outlet of the Pallas river; (ii) the March 1996 flood at the V station 
(a)

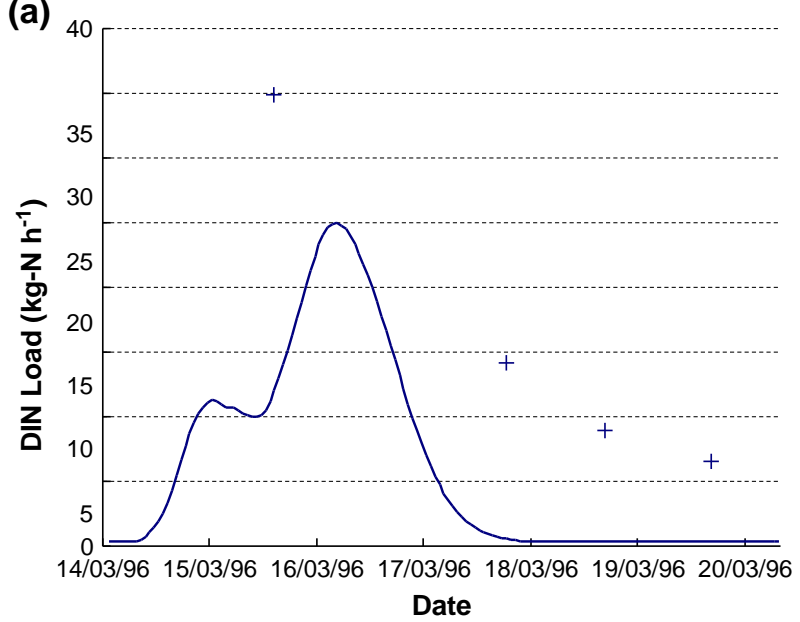

(b)

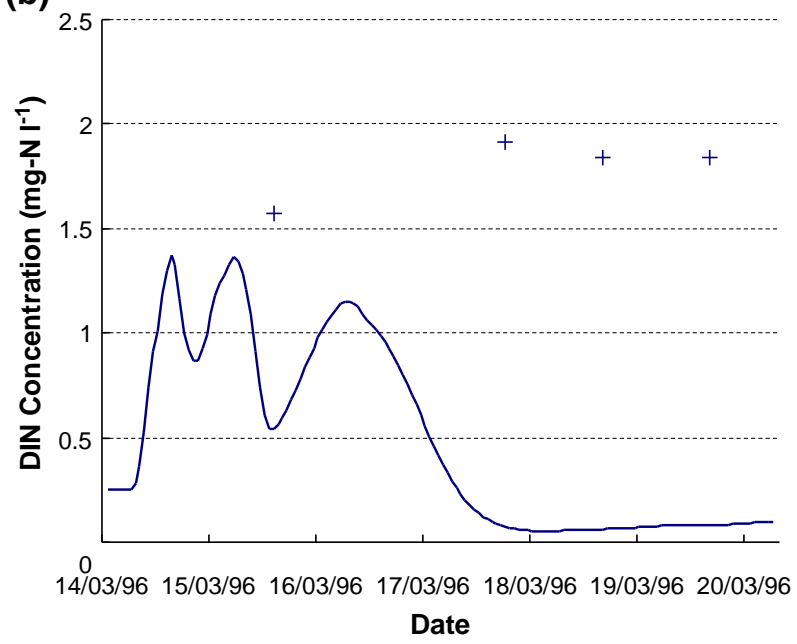

(c)

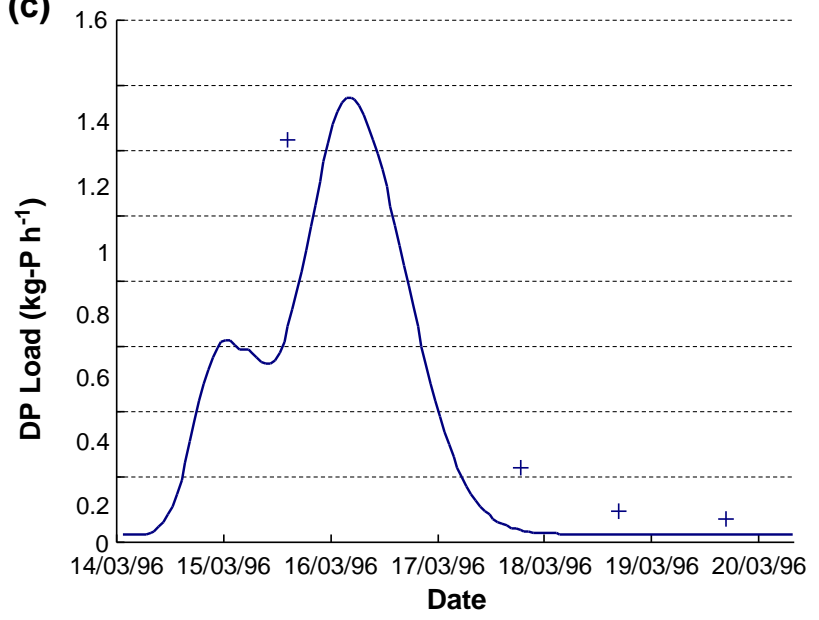

(d)

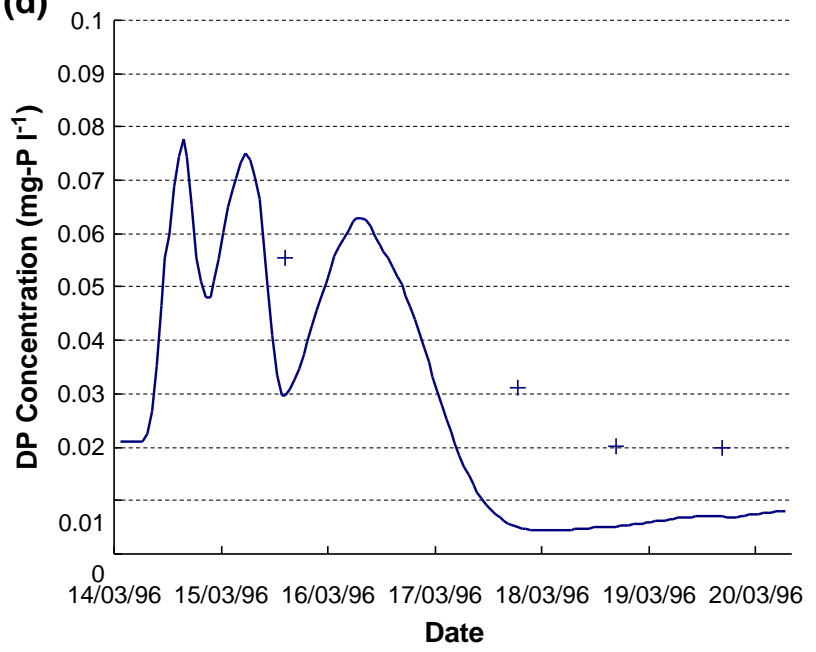

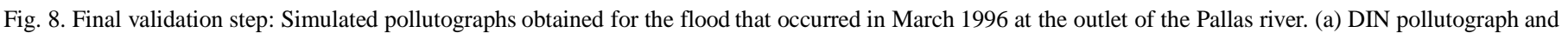
(b) DP pollutograph. Measured load (crosses) and simulated load (thin line).

of the Vène River; and (iii) the September 2003 event at the $\mathrm{O}$ station of the Vène River. The September 1994 event at the Pallas outlet was the first event of the autumn, consequently the catchment was dry at the beginning of the event. Not all the rainfall acted directly as pollutant drivers. That is certainly the reason why the total simulated load was greatly overestimated. The two events, March 1996 at the Vène outlet and September 2003 at the $\mathrm{O}$ station of the Vène basin are described by only five and three samples, respectively.

Nevertheless, except for these three events, DIN loads are in the right order of magnitude compared to observed loads and for most of them. If the error bars are taken into account, the simulated total loads and observed total loads are in accordance. Simulated DP loads (Fig. 9b) compare well with observed loads. Some loads are underestimated while others are over-estimated, but on average, the simulations are in agreement with the observations.

Actually, for both DIN and DP, two events of the validation subset gave total loads larger than the total loads observed in the calibration data set. Nevertheless, the D-PoL model estimates are in accordance with the observed values for those two large events.

\section{Conclusion}

In this study, we proposed an operational tool to estimate the pollutant loads transferred by small Mediterranean rivers during rainfall events. This tool is based on a conceptual and uncoupled model in order to reduce its complexity and the number of parameters required.

The model scheme was built taking into account the main processes in the transfer of pollutants in such river basins. The model is semi-distributed in such a way that production on the hillslopes and transport in the river can be taken into account. The model simulates pollutographs at the outlet of the catchment during rainfall events: rainfall triggers the processes. The model can be classified as a rainfall event-load model. The processes are described by three parameters: the initial stock of pollutants on the hillslopes, the production parameter (which is related to the lag time of the catchment) and the routing parameter (which is related to the lag time of a basic river reach). The sensitivity analysis demonstrated that each of the parameters controlled one key-feature of the pollutograph. The initial stock influenced the amplitude of the pollutograph, the 

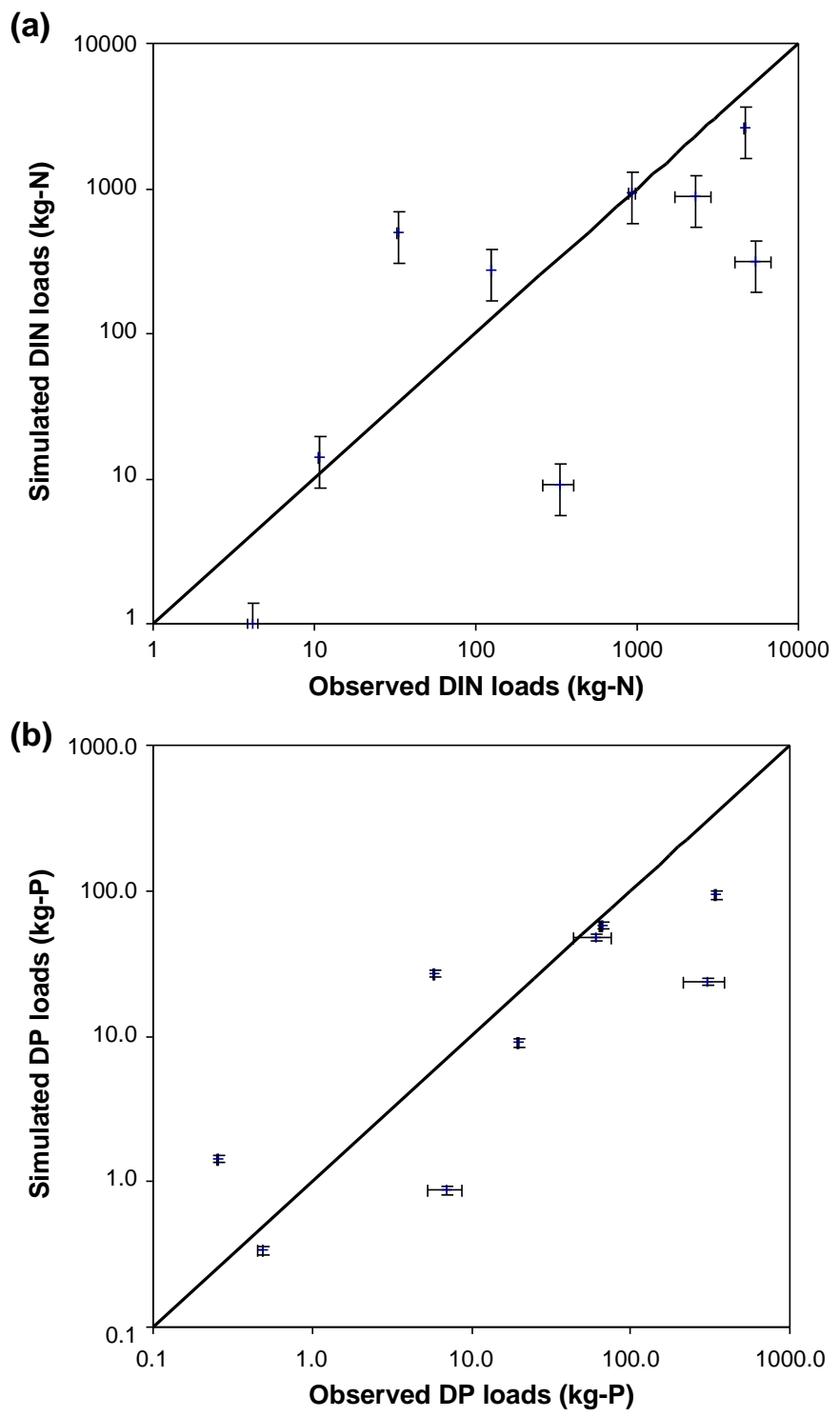

Fig. 9. Simulated loads plotted against observed ones for DIN (a) and DP (b). The error bars correspond to the relative error of the model as defined in the text and to the relative error of the sampling observation.

production parameter controlled the recession period and the routing parameter controlled the rising phase.

The model was calibrated using an original approach: (i) determination of the parameters that gave acceptable runs for the 20-flood calibration data set; (ii) adjustment of the optimal parameters to the descriptors of the rainfall events and the catchments and validation with the adjusted parameters on the calibration data set; and (iii) validation of the model with adjusted parameters, on the 10 -flood validation data set.

On the calibration data set, the simulated total loads with adjusted parameters compared satisfactorily with observed loads, except for very small events. For three quarters of the flood events, total loads were estimated by the model with an error less than $61 \%$ for DIN and $94 \%$ for DP. The validation of the model on a new 10-flood data set showed that the dynamics of pollutographs were not perfectly reproduced, but that simulated total loads are in agreement with the observed loads.

While we do not suggest that the D-PoL model built with the methodology described here models all the processes involved, it is a practical tool that is easy to apply. The model demonstrated its ability to give an estimation of pollutant loads transferred during rainfall events by small Mediterranean rivers. The parameter adjustment was specifically adapted for the three calibrated basins studied here. Nevertheless, the selected processes, production routing, offer a robust approach that could be applied to similar basins in which pol-

rameters are certainly sensitive to the basin and need to be pre-determined or at least validated. This study demonstrated that the behaviour and parameters of the three basins are similar even if urbanisation dominates in the Salaison basin.

\section{Acknowledgements}

This study would not have been possible without the financial support of the Programme National Environnement Côtier (PNEC) through the Chantier Lagunes Méditerranéennes. This research has been also assisted by the European Ditty Project (Development of an Information Technology Tool for the Management of European Southern Lagoons under the influence of river-basin runoff). Thanks are also due to D. Goodfellow for her editing jobs and to the reviewers for their valuable scientific comments and for their discerning recommendations.

\section{References}

Arnold, J.G., Srinivasan, R., Muttiah, R.S., Griggs, R.H., 1995. Watershed Modelling and GIS With SWAT and GRASS. SWAT User's Manual. Blackland Research Center, Texas Agricultural Experiment Station, Temple, TX.

Beasley, D.B., Huggins, L.F., 1985. ANSWERS: Areal Nonpoint Source Watershed Environment Response Simulation e User Manual. Agricultural Engineering Department, Purdue University, USA.

Bernal, S., Butturini, A., Sabater, F., 2005. Seasonal variations of dissolved nitrogen and DOC:DON ratios in an intermittent stream. Biogeochemistry 75, 351e372.

Bobba, A.G., Singh, V.P., Bengtsson, L., 2000. Application of environmental models to different hydrological systems. Ecological Modelling 25 (1), $15 \mathrm{e} 49$.

Bull, L.J., Kirkby, M.J., 2002. Dryland rivers: hydrology and geomorphology of semi-arid channels. In: Bull, L.J., Kirkby, M.J. (Eds.). Wiley, London.

Camarasa, A.M., Segura, F., 2001. Flood events in Mediterranean ephemeral streams (ramblas) in Valencia region (Spain). Catena 45, 229e249.

Campolongo, F., Kleijnen, J., Andres, T., 2000. Screening methods. In: Saltelli, A., Chan, K., Scott, E.M. (Eds.), Sensitivity Analysis. Wiley, Chichester.

Cassell, E.A., Dorioz, J.M., Kort, R.L., Hoffmann, J.P., Meals, D.W., Kirschtel, D., Braun, D.C., 1998. Modeling phosphorus dynamics in ecosystems: mass balance and dynamic simulation approaches. Journal of Environmental Quality 27 (2), 293e298.

Chapra, S.C., 1997. Surface Water-quality Modelling. WCB/McGraw-Hill, USA.

Cherifi, O., Loudiki, M., 1999. Flood transport of dissolved and suspended matter in the El Abid river basin (Morocco). Hydrobiologia 410, 287e294.

Croke, B.F.W., Jakeman, A.J., 2001. Predictions in catchment hydrology: an Australian perspective. Marine and Freshwater Research 52 (1), 65 e79. 
Donigian, A.S., Bicknell, B.R., Imhoff, J.C., 1995a. Hydrological simulation program-Fortran (HSPF). In: Singh, V.P. (Ed.), Computer Models of Watershed Hydrology. WRP, Highlands Ranch, Colorado, USA.

Donigian, A.S., Imhoff, J.C., Ambrose, R.B., 1995b. Modelling watershed water quality. In: Sigh, V.P. (Ed.), Environment Hydrology. Kluwer Academic Publishers, Netherlands.

Durand, P., Gascuel-Odoux, C., Cordier, M.O., 2002. Parameterisation of hydrological models: a review and lessons learned from studies of an agricultural catchment (Naizin, France). Agronomie 22 (2), 217 e228.

Eyre, B.D., Pont, D., 2003. Intra- and inter-annual variability in the different forms of diffuse nitrogen and phosphorus delivered to seven sub-tropical east Australian estuaries. Estuarine, Coastal and Shelf Science 57, 137 e148.

Fletcher, R., Powell, M.J.D., 1963. A rapidly convergent method for minimization. Computer Journal 6 (2), $163 \mathrm{e} 168$.

House, W.A., 2003. Geochemical cycling of phosphorus in rivers. Applied Geochemistry 18 (5), 739e 748.

Jordan-Meille, L., Dorioz, J.M., Mathieu, N., 1998. An artificial flood to determine the hydrological network's contribution to phosphorus exports in a small rural watershed. Water Research 32 (6), 1801e1810.

Kleijnen, J.P.C., 2005. An overview of the design and analysis of simulation experiments for sensitivity analysis. European Journal of Operational Research 164 (2), 287e300.

Krysanova, V., Muller-Wohlfeil, D.I., Becker, A., 1998. Development and test of a spatially distributed hydrological water quality model for mesoscale watersheds. Ecological Modelling 106 (2e3), 261e289.

Leon, L.F., Soulis, E.D., Kouwen, N., Farquhar, G.J., 2001. Nonpoint source pollution: a distributed water quality modelling approach. Water Research 35 (4), 997e 1007.

Letcher, R.A., Jakeman, A.J., Calfas, M., Linforth, S., Baginska, B., Lawrence, I., 2002. A comparison of catchment water quality models and direct estimation technique. Environment Modelling \& Software 17 (1), $77 \mathbf{e} 85$.

Margat, J., Treyer, S., 2004. L'eau des méditerranéens: situation et perspectives. Water for the people of the Mediterranean: present and future. Plan Bleu PNUE/PAM, MAP Technical Reports Series n 158.

McIntyre, N., Jackson, B., Wade, A.J., Butterfield, D., Wheater, H.S., 2005. Sensitivity analysis of a catchment-scale nitrogen model. Journal of Hydrology 315 (1e4), 71e92.

Merritt, W.S., Letcher, R.A., Jakeman, A.J., 2003. A review of erosion and sediment transport models. Environmental Modelling \& Software 18 (8e9), 761 e799.

Meybeck, M., 2005. Looking for water quality. Hydrological Processes 19 (1), 331 e 338.

Migliaccio, K.W., Chaubey, I., Haggard, B.E., 2007. Evaluation of landscape and instream modeling to predict watershed nutrient yields. Environmental Modelling \& Software 22 (7), 987e999.
Najem, W., Bocquillon, C., Jabbour, H., 2001. Analyse du fonctionnement hydrologique d'un bassin versant Libanais par une modélisation conceptuelle adaptée au climat méditerranéen: cas du Nahr Beyrouth. In: Servat, E., Albergel, J. (Eds.), Hydrologie des Régions Méditerranéennes. Montpellier, France.

Nash, J.E., Sutcliffe, J.V., 1970. River flow foresting through conceptional models, 1. A discussion of principles. Journal of Hydrology 10 (3), $282 \mathrm{e} 290$.

Newham, L.T.H., Letcher, R.A., Jakeman, A.J., Kobayashi, T., 2004. A framework for integrated hydrologic, sediment and nutrient export modelling for catchment-scale management. Environmental Modelling \& Software 19 (11), $1029 \mathrm{e} 1038$

Payraudeau, S., Tournoud, M.G., Cernesson, F., Picot, B., 2001. Annual nutrients export modelling by analysis of landuse and topographic information: case of a small Mediterranean catchment. Water Science and Technology 44 (2e3), 321 e 327.

Payraudeau, S., Tounoud, M.G., Cernesson, F., 2002. An adapted modelling approach for the nitrogen load management on a catchment scale. In: Hassanizadeh, S.M., Scotting, R.J., Gray, W.G., Pinder, G.E. (Eds.), Computational Methods in Water Resources. Development in Water Science 47 (2), 1741e1748. Elsevier.

Polyakov, V., Fares, A., Kubo, D., Jacobi, J., Smith, C., 2007. Evaluation of a non-point source pollution model, AnnAGNPS, in a tropical watershed. Environmental Modelling \& Software 22 (11), 1617e1627.

Rodriguez-Iturbe, I., Gupta, V.K., 1983. Scale problems in hydrology. Journal of Hydrology 65, 175e208.

Salles, C., Tournoud, M.G., Chu, Y. Estimating nutrient and sediment flood loads in a small Mediterranean river. Hydrological Processes, in press.

Saltelli, A., 2000. What is sensitivity analysis. In: Saltelli, A., Chan, K., Scott, E.M. (Eds.), Sensitivity Analysis. Wiley, Chichester.

Shrestha, S., Kazama, F., Newham, L.T.H., 2008. A framework for estimating pollutant export coefficients from long-term in-stream water quality monitoring data. Environmental Modelling \& Software 23 (2), 182 e194.

Sorooshian, S., Gupta, V.K., 1995. Model calibration. In: Singh, V.P. (Ed.), Computer Models of Watershed Hydrology. WRP, Highlands Ranch.

Vandenberghe, V., Bauwens, W., Vanrolleghem, P.A., 2007. Evaluation of uncertainty propagation into river water quality predictions to guide future monitoring campaigns. Environmental Modelling \& Software 22 (5), 725 e 732.

Wagener, T., McIntyre, N., Lees, M.J., Wheater, H.S., Gupta, H.V., 2003. Towards reduced uncertainty in conceptual rainfallerunoff modelling: Dynamic identifiability analysis. Hydrological Processes 17 (2), 455 e 476.

Yuan, D., Lin, B., Falconer, R.A., Tao, J., 2007. Development of an integrated model for assessing the impact of diffuse and point source pollution on coastal waters. Environmental Modelling \& Software 22 (6), 871e879.

Young, R.A., Onstad, C.A., Bosch, D.D., 1995. AGNPS: an agricultural nonpoint source model. In: Singh, V.P. (Ed.), Computer Models of Watershed Hydrology. WRP, Highlands Ranch. 